\title{
Work-related Migration and Unemployment
}

\author{
Tanja Fendel
}

Published online: 30. April 2014

(C) Institut für Arbeitsmarkt- und Berufsforschung 2014

\begin{abstract}
This paper examines the willingness of the unemployed to migrate in order to exit unemployment. The empirical estimation is based on data from the German Socio Economic Panel (GSOEP) from the years 2001 to 2009. Following a bivariate probit approach, results are obtained estimating the joint probability of being unemployed and to move to account for the endogeneity of the unemployment variable in the migration equation. The findings indicate that the probability of moving to exit unemployment is much lower compared to the work related moving probability of employed people. Material and in particular immaterial migration costs for the unemployed group appear to exceed the benefit of moving. Consequently, labour market policy should increase moving incentives for the unemployed and expand the regional interchange of employment agencies.
\end{abstract}

Keywords Interregional mobility · Unemployment ·

Migration · Germany

JEL classification $\mathrm{J} 62 \cdot \mathrm{J} 64 \cdot \mathrm{C} 35$

\section{Beschäftigungsmotivierte Umzüge und Arbeitslosigkeit}

Zusammenfassung Die vorliegende Studie analysiert die individuelle Umzugsbereitschaft von Arbeitslosen. Die ökonometrische Schätzung basiert auf Daten des Sozioökonomischen Panels für die Jahre 2001 bis 2009. Um die En-

Dipl. Vw. T. Fendel $(\bowtie)$

Free University Berlin, Berlin School of Economics and Law, Berlin, Deutschland

e-mail: Tanja.Fendel@fu-berlin.de dogenität der Arbeitslosen-Variable in der Migrationsgleichung zu berücksichtigen wird ein bivariates Probitmodell verwendet. Es schätzt die gemeinsame Wahrscheinlichkeit arbeitslos zu sein und umzuziehen um die Arbeitslosigkeit zu beenden. Die Ergebnisse belegen, dass die arbeitsbedingte Umzugswahrscheinlichkeit von Arbeitslosen sehr viel niedriger ist als die von Beschäftigten. Für die Arbeitssuchenden erscheinen materielle und vor allem immaterielle Umzugskosten deutlich höher auszufallen als der resultierende Umzugsnutzen. Die aus diesen Ergebnissen zu ziehenden Forderungen an die Arbeitsmarktpolitik wären die Umzugsanreize für Erwerbslose zu erhöhen, ihnen Vorschläge über entfernte Stellenangebote zu unterbreiten sowie den regionalen Austausch von Jobcentern auszubauen.

Schlüsselwörter Interregionale Mobilität ·

Arbeitslosigkeit · Migration · Deutschland

\section{Introduction}

The situation on the German labor market has changed for the better over the last $8-9$ years. Whereas in 20054.9 million people were unemployed, the number decreased to 2.9 million in December 2013 (German Federal Employment Agency). Yet, the individual situation of the 3 million unemployed remains unimproved. Individual unemployment is still highly distressing and affects all areas of life. This study focuses on the possibility of ending unemployment by moving to another region for a new occupation. Most people are regionally bound to a particular area; often the family situation makes work-related moving difficult and moving is associated with high costs. However, many individuals and families overcome these obstacles successfully. The question thus arises of whether in Germany the 
unemployed are as willing to move as employed workers to escape unemployment. A lower willingness to move among the unemployed is likely to imply that certain moving obstacles only exist for this group or are at least of greater significance for them. In this case, for labor market policy the potential would exist to reduce unemployment by reducing moving obstacles. This study questions whether being unemployed increases or decreases the probability of undertaking a job motivated change of residence.

There are arguments for and against a higher job mobility of the unemployed. It can be assumed that rational utility-maximizing individuals compare the payoffs of different opportunities when a decision for migration needs to be made. According to Todaro (1976) the migration decision is governed by the expected differential between the income in the home and potential destination regions. Pursuant to this approach, unemployed people are more likely to consider a change of residence than employed workers due to the expected gain in income. Further positive effects are lower opportunity costs for the unemployed, for example due to no loss of firm specific human capital (Juerges 1998). Previous US-studies confirm that the unemployed are more likely to migrate than employed people (DaVanzo 1978; Gross and Schoening 1984). On the contrary, the expected increase in income may not be sufficient due to regional price differences especially in housing costs. This applies especially for individuals with low qualifications and consequently low wages. The usually precarious financial situation of (long-term) unemployed job seekers might deter them from considering a change of residence even though basic moving expenses are usually paid by the employment agency once the work-related migration is approved. Windzio (2004) emphasizes that not only opportunity differences between source and destination regions will influence the migration decision. Individual characteristics, especially in terms of human capital resources also influence the decision. A broader identification of moving motives is achieved by substituting monetary migration payoffs with overall utility increases. Non-monetary migration costs result for example from leaving familiar surroundings. A person may also be discouraged from moving by general personal inflexibility. Furthermore, Kitching (1990) attributes the lack of mobility among unemployed people predominantly to their on average lower educational level. A lower educational level can be assumed since it is per se related to a higher unemployment risk (Glocker and Steiner 2011). Many migration studies emphasize the high influence of education on mobility (Long 1973; Greenwood 1975; Karr and Koller 1987; Massay 1993; Haas 2000; Windizo 2004; Arntz 2005; Dustmann and Glitz 2011). When migration is understood as an investment decision the economic success of the migrant in the new destination is highly influenced by his or her educa- tional background (Sjaastad 1962). In addition, it is often assumed that individuals with low education are less likely to get information about vacancies in other regions and to consider moving for a new job (Juerges 1998).

Using a bivariate probit approach and micro data from the German Socio Economic Panel, the present study analyzes whether the unemployment status has a positive effect on labor mobility. The findings indicate that the probability of moving in order to exit unemployment is much lower compared to the work-related moving probability of employed workers. Other empirical studies on this question are usually based on the IAB Regional File and show mixed results. With regard to labor market conditions, Windzio (2004) divides West Germany into superior south and inferior north regions. He asks which determinants mainly influence labor mobility between southern and northern states. A three-level time discrete model is used embedding individual years in regional years that depend on the specific region. The model can refer to individual and context specific factors. Windzio's results indicate that migration probability increases with either an academic degree or an unemployment status. Thus, the probability decreases with unemployment duration and for individuals in regions with high unemployment rates. In a following study, Windzio (2008) looks at the mobility rates of the East German unemployed to the West German labor market applying a frailty hazard model for clustered data. His results indicate that migration probability increases with an academic degree but decreases with the distance to the East/West-border. Arntz (2005) concentrates on the migration behavior of West German unemployed jobseekers. She finds contradicting effects. She uses a competing-risk search-theoretic framework to estimate hazard rates for exiting unemployment to jobs in a local or distant labor market area. Comparable to the aforementioned studies, the approach assumes that migration probabilities do not only depend on exogenous labor market factors but also on endogenous search strategies and therefore on individual factors. Arntz' empirical results indicate that the unemployed choose search strategies that promote leaving local labor markets with inferior conditions. In addition her study indicates that the willingness to migrate increases with unemployment duration and qualification level.

The outline of this paper is as follows. The next section introduces the empirical model and provides justification for choosing the model. The data set used is described in the third part. Estimation results are discussed in the fourth section. Section five concludes.

\section{Model specification}

This analysis of the effect of unemployment on labor mobility is based on data from the German Socio Economic 
Panel. The SOEP allows controlling for the most important determinants of migration such as education and family circumstances. Yet, it can be assumed that there are unobservable variables that influence labor-motivated migration decisions and, in a somewhat similar way, the probability of being unemployed. The hypothesis is that the two binary responses are correlated through unobservable variables. An endogeneity bias is likely to occur when a binary response model is used to estimate the influence of the unemployment status on the job-migration probability. If the error terms are correlated, an unbiased effect is estimated by jointly determining the two outcomes. A bivariate probit model tests whether the binary job-migration decision and the binary response of being unemployed are jointly determined. As a result, this model estimates the joint probability of being unemployed and its influence on the job-migration decision (Greene 2010).

It can be assumed that the binary job-migration decision and the unemployment status are interrelated as expressed by the following model structure:

$$
\begin{aligned}
& \mathrm{y}_{1}^{*}=\alpha_{1} \mathrm{y}_{2}+\boldsymbol{\beta}_{1}^{\prime} \mathbf{x}_{1}+\varepsilon_{1} \\
& \mathrm{y}_{2}^{*}=\boldsymbol{\beta}_{2}^{\prime} \mathbf{x}_{2}+\varepsilon_{2}
\end{aligned} \text { with }\left\{\begin{array}{l}
y_{1}=1 \text { if } y_{1}^{*}>0 \\
y_{2}=1 \text { if } y_{2}^{*}>0
\end{array}\right.
$$

The observed binary outcome variable $y_{j}($ with $j=1$ for the job-migration decision and $\mathrm{j}=2$ for the unemployment status) is defined as follows. $y_{1}$ equals 1 when a person moved due to work related issues and $y_{1}$ equals 0 if the person did not move. $y_{2}$ equals 1 when a person is registered as unemployed and equals 0 otherwise. $\mathrm{y}_{\mathrm{j}}$ is assumed to be determined by an underlying unobserved "latent" variable $y_{j}{ }^{*}$. In this function $\mathrm{x}_{\mathrm{j}}$ represents a vector of exogenous variables including a constant whilst $\varepsilon_{\mathrm{j}}$ is the vector of residuals. For the job-related migration decision the latent variable $\mathrm{y}_{1} *$ can be interpreted as the probability of moving due to workrelated issues and for the unemployment status $\mathrm{y}_{2}{ }^{*}$ can be termed the "unemployment propensity" (Verbeek 2004).

It can be assumed that $y_{j}{ }^{*}$ follows a bivariate normal distribution where the errors are dependent on one another:

$$
\begin{aligned}
& \mathrm{y}_{1}^{*}, \mathrm{y}_{2}^{*} \sim \Phi_{2} \\
& \operatorname{Corr}\left(\varepsilon_{1}, \varepsilon_{2}\right)=\rho
\end{aligned}
$$

Here $\Omega_{2}$ represents the cumulative bivariate normal distribution. The marginal probabilities of $y_{1}$ and $y_{2}$ are

$$
\operatorname{Pr}\left(\mathrm{y}_{2}=1 \mid \varepsilon_{2}, \mathbf{x}_{2}\right)=\mathrm{P}\left(\varepsilon_{2}>-\boldsymbol{\beta}_{2}^{\prime} \mathbf{x}_{2}\right)=\Phi\left(\boldsymbol{\beta}_{2}^{\prime} \mathbf{x}_{2}\right)
$$

and

$$
\begin{aligned}
\operatorname{Pr}\left(\mathrm{y}_{1}=1 \mid \varepsilon_{1}, \mathbf{x}_{1}\right) & =\mathrm{P}\left(\varepsilon_{1}>-\left(\alpha_{1} \mathrm{y}_{2}+\boldsymbol{\beta}_{1}^{\prime} \mathbf{x}_{1}\right)\right. \\
& =\Phi\left(\alpha_{1} \mathrm{y}_{2}+\boldsymbol{\beta}_{1}^{\prime} \mathbf{x}_{1}\right)
\end{aligned}
$$

Since the two probabilities are not independent, conditional probability has to be used to calculate the joint probability: $\operatorname{Pr}(\mathrm{A} \& \mathrm{~B})=\operatorname{Pr}(\mathrm{A} \mid \mathrm{B}) \times \operatorname{Pr}(\mathrm{B})$. The probability of moving, given that a person is unemployed and given $\mathbf{x}$, is

$$
\begin{aligned}
\operatorname{Pr}\left(\mathrm{y}_{1}=1 \mid \mathrm{y}_{2}=1, \mathbf{x}\right) & =\int_{-\beta_{2}^{\prime} \mathrm{x}_{2}}^{\infty} \Phi\left[\frac{\alpha_{1} \mathrm{y}_{2}+\boldsymbol{\beta}_{1}^{\prime} \mathbf{x}_{1}+\rho \varepsilon_{2}}{(1-\rho)^{\frac{1}{2}}}\right] \varphi\left(\varepsilon_{2}\right) \mathrm{d} \varepsilon_{2} \\
& =\Phi\left(\alpha_{1} \mathrm{y}_{2}, \boldsymbol{\beta}_{1}^{\prime} \mathbf{x}_{1}, \boldsymbol{\beta}_{2}^{\prime} \mathbf{x}_{2}, \rho\right)
\end{aligned}
$$

where $\varphi$ represents the density function of bivariate normal distributed variables. The coefficients are estimated using maximum likelihood methods. (Greene 2008). Similar to the standard probit model, each observation contributes some combination of $\operatorname{Pr}\left(y_{j}=1\right)$ for $j \in 1,2$ depending on the specific value of these variables (Maddala 1983). Denoting $\operatorname{Pr}\left(\mathrm{y}_{1}=1 \mid \mathrm{y}_{2}=1, \mathbf{x}\right) \equiv \operatorname{Pr}_{11}$, etc. the likelihood function is

$$
\begin{aligned}
& \mathrm{L}\left(\boldsymbol{\beta}_{1}, \boldsymbol{\beta}_{2}, \alpha_{1}, \rho\right) \\
& \quad=\Pi\left[\operatorname{Pr}_{11}^{\mathrm{y}_{1}, \mathrm{y}_{2}} \operatorname{Pr}_{10}^{\mathrm{y}_{1}\left(1-\mathrm{y}_{2}\right)} \operatorname{Pr}_{01}^{\left(1-\mathrm{y}_{1}\right) \mathrm{y}_{2}} \operatorname{Pr}_{00}^{\left(1-\mathrm{y}_{1}\right)\left(1-\mathrm{y}_{2}\right)}\right]
\end{aligned}
$$

Labor mobility of the unemployed can also be analyzed by estimating a treatment effect in the presence of non-random assignment. Instead of estimating the influence of unemployment on the job-migration probability, the moving probability of the unemployed is compared to that of employed people. When comparing the probabilities an endogeneity problem arises since it cannot be assumed that people are randomly distributed as employed or unemployed. Therefore, the difference between the two probabilities will not give the treatment effect. To improve the evidence, the jobmigration probability of the unemployed can be compared to the average of the probability for matched employed people. Within the propensity score matching method matches can be applied on the basis of the observed characteristics $\mathrm{x}_{2}$ determining the probability of being unemployed (Heckman et al. 1998). The method is mainly superior to the regression approach when the data is not representative since the number of observations is low in some sections. While in this case results of the regression estimation are based on a small number of cases for some parts of the estimated function, results of the non-parametric matching method are based on the area of common support of $x_{2}$. However, it has been pointed out that the propensity score matching method does not work better in large samples (Guo and Fraser 2013). With a total of 9,971 people over nine years and 6,390 unemployment periods, the number of pooled observations is quite high in the data set used. Furthermore, the GSOEP is highly representative for Germany. Therefore, the regression approach is expected to give significant and accurate results. 
An alternative approach, allowing for the correlation of unobserved characteristics is the endogenous switching regression method. Here, the probability of unemployment, the probability of moving when being unemployed and the probability of moving when not being unemployed are determined jointly as probit regressions. Again, the two moving probabilities can be compared. Similar to the bivariate probit model used in this study, the covariances of the disturbances provide information about the selectivity of the unemployed and the employed for the migration probability (Winship and Mare 1992). Results are expected to be quite similar. However, since both outcomes, the jobmigration decision and the unemployment status, are binary responses and are both assumed to have underlying unobserved "latent" variables, this model is more complicated than the model with structural shift given in (1).

To be logically consistent, models with latent variables and their dichotomous observations in different structural equations need some restrictions on the coefficients. On the one hand in (1) the observed counterpart $\mathrm{y}_{2}$ of the second dependent variable $y_{2}^{*}$ appears on the right-hand side of the first equation. On the other hand $\mathrm{y}_{1}$ does not appear in the second equation. Maddala (1983) showed that simultaneous equation models in which the second equation has the form $\mathrm{y}_{2}^{*}=\alpha_{2} \mathrm{y}_{1}+\boldsymbol{\beta}_{2}^{\prime} \mathbf{x}_{2}+\varepsilon_{2}$ are logically inconsistent unless $\alpha_{1}=0$ or $\alpha_{2}=0$. If $\alpha_{1} \alpha_{2} \neq 0$, the probabilities would not sum up to 1 . Since the analysis is conducted on the individual level and only job motivated moves are relevant, the model is in line with the contents. On the regional level there are arguments for simultaneity. The regional unemployment rate may not only influence the regional mobility rate. Mobility is also likely to influence the regional labor market conditions. If a region faces high migration flows from other regions, there is a high probability that labor market circumstances in this region will change. However, in this study based on the individual level, the mobility variable equals 1 when a person moved due to work-related issues. Therefore a person moves to directly change his or her own employment status for the better. This migration variable in the unemployment equation would therefore not only influence the unemployment probability but directly determine it.

In addition to conditions for logical consistency, identifiability conditions must be fulfilled. For models such as the one given in (1) in which the error terms are not independent, the parameters are not identified if $\mathbf{x}_{1}$ includes all the variables considered in $\mathbf{x}_{2}$ (Maddala 1983). Identification is reached by distinguishing the two structural equations with exclusion restrictions. Since the unemployment variable $y_{2}$ in the migration equation suffers from endogeneity, a variable in the unemployment equation is required that explains the unemployment status but is exogenous to the mobility equation. The exclusion restriction is a variable that affects the employment probability while not being correlated with the probability of moving conditional on the other covariates (Dujardin and Goffette-Nagot 2009). This applies for the gender variable. On the one hand being female should not influence the moving decision. For the given sample estimation results confirm this assumption. It is plausible that in the past the mobility rate of men used to be higher than that of women due to the better educational opportunities men enjoyed. The probability of relocating to study or for a new occupation was probably much higher among men than among women. Today this difference is not longer apparent. The Federal Institute for Population Research even pointed out that in 2010 young women were more mobile than young men. However, this applies only to age 18-27 (Bundesinstitut für Bevölkerungsforschung 2010). On the other hand the probability of being registered as unemployed is lower for women as indicated by the given sample as well as by data from the Federal Statistic Office. Since unification, the difference in unemployment risks between women and men has diminished. In fact, there are more opportunities for women than for men not to work without being registered as unemployed. While it is still common among women to stay at home and raise the children while living on their spouses' income, men usually do not make use of this opportunity.

Although it is not needed for identification, a variable is integrated in the moving equation which does not influence the unemployment probability. It can be assumed that this applies for cases in which a person is a dwelling-owner or renter (see sect. 3).

\section{Data and descriptive statistics}

This analysis of the influence of unemployment on labor mobility is based on data from the German Socio Economic Panel. The GSOEP ${ }^{1}$ is an ongoing representative panel survey of private households in Germany. Introduced in 1984 it is the oldest longitudinal section study of private households in Germany and enjoys high international recognition. It allows longitudinal examinations as well as the conjunction of personal and household data. Most of the existing studies on the mobility of unemployed people have used data focusing on labor market factors. For Germany the $\mathrm{IAB}^{2}$ employment subsamples (IAB-Beschäftigungstichproben, IABS) are most commonly used. The IABS contain information on the employment histories of employees entitled to social security benefits on a daily basis. Unfortunately periods of registered unemployment cannot be identified. The data

${ }^{1}$ For more information on the GSOEP see www.diw.de/soep and Haisken-DeNew and Frick (2001).

${ }^{2}$ Institute for Employment Research. 
includes information on periods during which individuals received unemployment compensation. Alternative financial resources such as spousal income are not recorded separately. Therefore it is not possible to distinguish between those who have left the labor force and those who are still unemployed but do not receive any unemployment compensation (Arntz 2005). The SOEP distinguishes between registered unemployment and non-working periods due to other reasons such as maternity leave. The dataset is also superior since it contains information on additional determinants of migration such as family circumstances. Migration research usually points out that the decisions to migrate is in most cases not made by workers or employees alone but by households (Mincer 1977; Rossi 1980; Linnemann 1983).

In 2000 the SOEP doubled the household sample size. The number of moving households is generally low and their attrition (as well as that of new households in their first year) is high. Therefore, this analysis uses data from years 2001 to 2009. The study takes an individual-level approach. The SOEP-questionnaire asks whether a person was living in the same place a year ago. On the household level up to three motives for moving can be named. Figure 1 depicts the main reasons for moving (categories are subsumed). The shares do not sum up to $100 \%$ as the category "other reasons" is not included. As shown in the figure, occupation related moves are not undertaken anywhere near as often as housing or family related moves.

Another motivation for unemployed people to move presumably lies in the fact that they are not entitled to receive housing benefit when their current residence is too large. The additional question whether the moving reason is "related to work" ensures that these cases are excluded. In this case the central moving variable "MOVE_JOB" equals 1 and 0 if a person did not move. Other reasons for relocation are therefore not relevant and excluded. Here a missing value is generated for the MOVE_JOB variable. For the data used on the individual level the work-related moving probability has a yearly average value of 0.008 and a standard deviation of 0.0892 .

Comparable studies usually estimate unemployment duration models and take into account the influence of the duration of unemployment on the willingness to move (Ahn et al. 1998; Arntz 2005). Due to the low number of moves per year in the SOEP, the empirical analysis of this study is based on pooled data. Only the unemployment status itself, but not its duration is considered. The central unemployed status dummy variable (UNEMPL, (t-1)) displays periods of registered unemployment and has a yearly average value of 0.0892 with a standard deviation of 0.2851 in the data used. The estimation focuses on the question of whether the unemployment status of the previous period has an influence on the circumstance that the person moved due to jobrelated issues between the previous and the current year.

Since the moving probability of working age individuals is of interest in this study, the used data set is restricted to household members of ages 18-65. For this group the data set provides repeated measurements on moving and employment issues for about 9,971 people and 7,724 households. Robust standard errors are computed to account for correlation of the errors between household members. $25 \%$ of the people (under 66 years of age) are living in the former East Germany area and $53 \%$ of the people in the sample are women. In sum 6,225 relocations with 768 job-motivated moves were observed. A residential change was observed in 554 out of 6,571 unemployment periods, including 52 job motivated moves.

The following passage discusses the expected influence of the explanatory variables used in the estimation. Table 1 depicts the means and standard errors of shares for the respective variables. The table differentiates for the group of people in the sample who decided to move for work-related reasons and those who have been unemployed in at least one relevant year. Similar to the estimation only people under 66 years of age are considered.
Fig. 1 Most important moving reasons for SOEP-households in $\%$. (Source: SOEP)

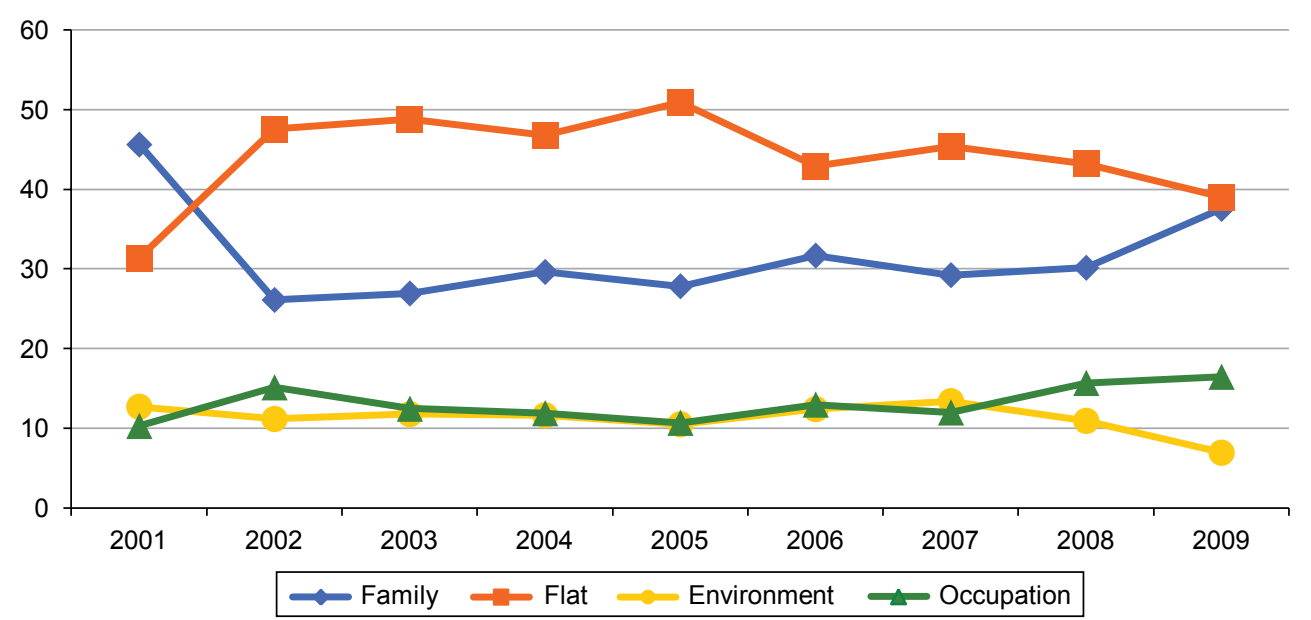


Table 1 Mean and standard deviation of average shares for explanatory variables and separated for the group of moving and unemployed persons. (Source: SOEP)

\begin{tabular}{|c|c|c|c|}
\hline & Total & $\begin{array}{l}\text { Job- } \\
\text { motivated } \\
\text { moves }\end{array}$ & $\begin{array}{l}\text { Unem- } \\
\text { ployed }\end{array}$ \\
\hline Education (in years) & $\begin{array}{l}12.17 \\
(2.54)\end{array}$ & $\begin{array}{l}13.70 \\
(2.94)\end{array}$ & $\begin{array}{l}11.33 \\
(2.12)\end{array}$ \\
\hline Age (in years) & $\begin{array}{l}44.73 \\
(11.92)\end{array}$ & $\begin{array}{l}33.59 \\
(9.39)\end{array}$ & $\begin{array}{l}45.86 \\
(11.56)\end{array}$ \\
\hline Health (in 5 categories) & $\begin{array}{l}3.45 \\
(0.89)\end{array}$ & $\begin{array}{l}3.77 \\
(0.84)\end{array}$ & $\begin{array}{l}3.18 \\
(0.96)\end{array}$ \\
\hline HH-Size (in persons) & $\begin{array}{l}2.86 \\
(1.27)\end{array}$ & $\begin{array}{l}2.04 \\
(1.13)\end{array}$ & $\begin{array}{l}2.69 \\
(1.30)\end{array}$ \\
\hline Single (in \%) & $\begin{array}{l}33.36 \\
(0.47)\end{array}$ & $\begin{array}{l}67.14 \\
(0.47)\end{array}$ & $\begin{array}{l}45.68 \\
(0.50)\end{array}$ \\
\hline Children less than 16 (in \%) & $\begin{array}{l}35.69 \\
(0.48)\end{array}$ & $\begin{array}{l}24.22 \\
(0.43)\end{array}$ & $\begin{array}{l}32.68 \\
(0.47)\end{array}$ \\
\hline German (in \%) & $\begin{array}{l}93.00 \\
(0.26)\end{array}$ & $\begin{array}{l}93.36 \\
(0.25)\end{array}$ & $\begin{array}{l}89.94 \\
(0.30)\end{array}$ \\
\hline Other income (in $€$ ) & $\begin{array}{l}1588.58 \\
(1303.73)\end{array}$ & $\begin{array}{l}997.62 \\
(1011.10)\end{array}$ & $\begin{array}{l}1211.6 \\
(951.48)\end{array}$ \\
\hline Partner unemployed (in \%) & $\begin{array}{l}7.44 \\
(0.26)\end{array}$ & $\begin{array}{l}1.03 \\
(0.31)\end{array}$ & $\begin{array}{l}6.11 \\
(0.42)\end{array}$ \\
\hline Owner (t-1) (in \%) & $\begin{array}{l}52.40 \\
(0.50)\end{array}$ & $\begin{array}{l}17.68 \\
(0.38)\end{array}$ & $\begin{array}{l}33.11 \\
(0.47)\end{array}$ \\
\hline Gender (female, in \%) & $\begin{array}{l}52.86 \\
(0.50)\end{array}$ & $\begin{array}{l}53.26 \\
(0.50)\end{array}$ & $\begin{array}{l}52.02 \\
(0.50)\end{array}$ \\
\hline Number of observations & 81,600 & 768 & 6,571 \\
\hline
\end{tabular}

Standard errors in parentheses

The following personal and household specific exogenous variables appear in both equations in $\mathbf{x}_{1}$ and $\mathbf{x}_{2}$ and are therefore assumed to influence the migration and the unemployment probability: The educational level measured in years is included in both equations. The variable EDUCATION ranges from 7 to 18 years for the observed data. The variable does not distinguish between school and vocational education. In migration literature, education is one of the main determinants of migration (Long 1973). This is especially true for this study, since the examination looks only at job-motivated relocations. A positive effect is assumed due to expected increasing economic success. The sample's average number of years of education is $12.17,13.70$ for people who moved for a work-related issue and 11.33 for people who were unemployed in one of the observed years (see Table 1). AGE and HEALTH are also expected to influence both probabilities. AGE is measured in years and five groups are built: (18-20); (21-27); (28-35) and (36-65). Each group is represented by a dummy variable. Most job changes are expected to take place before the age of 36 . Therefore, the category $36-65$ with a share of $60 \%$ is quite large. The average age of individuals (under 66) is 44.73 years. While younger people are expected to have a higher probability for job-related relocation (the average age for this group in the sample is 33.59), the effect on the unemployment status is not intuitively given. According to the German Federal Employment Agency the age groups 15-25 and 50-65 years have the highest unemployment probability (Bundesagentur für Arbeit 2012). The average age of the unemployed in the given sample is 45.86. Information on HEALTH is based on people's estimation of their health status on a scale of 1 to 5 , from bad (1), less good (2), satisfying (3), good (4) to very good (5). Health is assumed to have a positive effect on the job motivated moving probability and a negative effect on the unemployment probability. The average health status in the sample is about 3 for all people and for the unemployed and 4 for people willing to relocate.

Not only personal characteristics but also the family situation adds to the migration decision and labor market situation. The household size (HH-SIZE) is considered in both equations and ranges from 1 to 14 with an average value of 2.86 people in the data used. It can be assumed that the smaller the household, the easier a decision to move due to a new occupation is made. The average number of household members among the people willing to move is 2.04 and 2.69 among unemployed people. The same line of argument for the effects on migration of the household size may apply for the following two considered variables. Being SINGLE is assumed to have a positive effect on the moving probability. Separated and divorced people are also considered as single and make up an average share of $33 \%$ of the sample. Here, about $67 \%$ (46\%) of moving (unemployed) people are single. The existence of CHILDREN under 16 years of age in the household is assumed to have a negative effect on the moving probability. The average share amounts to $36 \%$ and about $24 \%$ (33\%) of moving (unemployed) people have young children

In both equations the existence of a migration background is considered in the form of a dummy variable (GERMAN) which equals 1 for Germans. $93 \%$ of the observed individuals are German. Almost the same value (93.36) applies for moving people. Thus they can be assumed to be less mobile compared to individuals with a migration background. In contrast, a negative effect on unemployment can be expected. The share of unemployed Germans in this sample amounts to $90 \%$. Examinations using data from the "Bundesagentur für Arbeit" and "Mikrozensus" have shown that individuals with a migration background are about twice as likely to be unemployed (Seebaß and Siegert 2011). The household's income situation is also considered for both equations. Since the income in unemployment households is usually lower than that of employed people this is not a useful explanatory variable. Therefore "other income" (O_INCOME) is used meaning the available income after subtracting the individual net income of employed workers. For the unemployed the unemployment benefit (ALG I) or unemployment compensation (ALG II) is subtracted. 
The average value of "other income" in the sample amounts to $€ 1,588$ and $€ 1,212$ for unemployed people. "Other income" is expected to have a negative effect on unemployment parallel to the effect of the individual's or household's educational level. Due to consistency "other income" is also used for the migration equation. The variable can have both a positive or negative influence. On the one hand, a higher probability can be assumed again due to the correlation between qualification and income in the household. On the other hand, another person in the household with a well-paid job might be a deterrent from work related relocation. The average value in the sample is $€ 997.62$ for moving people. The value is scaled at 1,000 for this estimation. It can also be assumed that the employment status of the spouse or partner is relevant for job-migration decisions and for the individual unemployment status. Therefore, a dummy variable displaying whether the partner is unemployed (P_UNEMPL $=1)$ or not $(=0)$ is integrated into both equations. Moving due to a spouse's working situation is expected to be easier when the other spouse is not forced to look for a new occupation or commuting option. Furthermore, it has often been pointed out that the unemployment probability is higher when the partner is unemployed, too. On average $7 \%$ of all people, $1 \%$ of the moving people and $6 \%$ of the unemployed people in the sample have a partner who is unemployed. To control for regional and time effects both equations include year- and regional dummies. The latter are based on the German Bundesländer (NUTS 1 level).

The vector of explanatory variables $\mathbf{x}_{1}$ for the migration equation contains the dummy variable OWNER (t-1) with an average share of $52 \%$ in the observed data. It can be assumed that a dwelling-ownership is relevant for the jobmoving decision while it is not influencing the unemployment status. The vector of explanatory variables $\mathbf{x}_{2}$ for the unemployment equation contains the dummy variable GENDER with an average share of $53 \%$ of women in the sample. While it can be assumed that the moving probability is not influenced by the gender the probability of being unemployed should be lower for women (see sect. 2). Therefore the variable functions as an exclusion restriction for estimating the causal effect of being unemployed on regional mobility. The average share of female moving persons in the sample is also $53 \%$ and $52 \%$ for unemployed women.

\section{Results}

Table 2 below depicts the results of the bivariate probit model. The bivariate probit model tests whether the two discrete equations about the decision to change residence and the unemployed status are interrelated by unobservable factors. Furthermore, the model determines the joint probability to move and to be unemployed and estimates the
Table 2 Estimated coefficients of the two probit system

\begin{tabular}{|c|c|c|c|c|}
\hline \multirow[b]{2}{*}{ UNEMPL (t-1) } & \multicolumn{2}{|c|}{ Job-Mobility } & \multicolumn{2}{|c|}{ Unemployed (t-1) } \\
\hline & $-0.8190^{c}$ & $(0.3138)$ & - & - \\
\hline OWNER (t-1) & $-0.7450^{c}$ & $(0.0818)$ & - & - \\
\hline EDUCATION & $0.0364^{\mathrm{b}}$ & $(0.0156)$ & $-0.0765^{\mathrm{c}}$ & $(0.0051)$ \\
\hline SINGLE & 0.0255 & $(0.0795)$ & $0.2072^{\mathrm{c}}$ & $(0.0353)$ \\
\hline CHILDREN & $0.2214^{\mathrm{b}}$ & $(0.0960)$ & $-0.0488^{\mathrm{a}}$ & $(0.0282)$ \\
\hline O_INCOME & -0.0450 & $(0.0304)$ & $-0.0312^{\mathrm{c}}$ & $(0.0099)$ \\
\hline AGE_-20 & $-4.7322^{c}$ & $(0.2801)$ & $-4.1706^{c}$ & $(0.2000)$ \\
\hline AGE_21-27 & \multicolumn{2}{|c|}{ Base category } & \multicolumn{2}{|c|}{ Base category } \\
\hline AGE_28-35 & 0.0255 & $(0.1425)$ & -0.0446 & $(0.0941)$ \\
\hline AGE_36-65 & -0.2121 & $(0.1374)$ & 0.0357 & $(0.0909)$ \\
\hline HEALTH & 0.0479 & $(0.0363)$ & $-0.1224^{c}$ & $(0.0115)$ \\
\hline GERMAN & $-0.2336^{b}$ & $(0.0969)$ & $-0.3972^{\mathrm{c}}$ & $(0.0363)$ \\
\hline HH-SIZE & $-0.1290^{b}$ & $(0.0519)$ & $0.0318^{\mathrm{c}}$ & $(0.0119)$ \\
\hline P_UNEMPL (t-1) & $0.2092^{\mathrm{a}}$ & $(0.1112)$ & $0.5618^{c}$ & $(0.0292)$ \\
\hline GENDER & - & - & $-0.0575^{\mathrm{c}}$ & $(0.0217)$ \\
\hline Constant & $-2.0855^{\mathrm{c}}$ & $(0.3551)$ & $-0.4183^{c}$ & $(0.1263)$ \\
\hline Year dummies & $\sqrt{ }$ & & $\sqrt{ }$ & \\
\hline German state dummies & $\sqrt{ }$ & & $\sqrt{ }$ & \\
\hline \# Observations & \multicolumn{4}{|l|}{40,357} \\
\hline Corr. of residuals, $\rho$ & \multicolumn{4}{|c|}{$0.5105^{\mathrm{b}}(0.1980)$} \\
\hline Log likelihood & \multicolumn{4}{|c|}{-10655.045} \\
\hline LR test & \multicolumn{4}{|l|}{4.4278} \\
\hline
\end{tabular}

Standard errors in parentheses

${ }^{\mathrm{a}}$ significant at $10 \%$, ${ }^{\mathrm{b}}$ at $5 \%$, ${ }^{\mathrm{c}}$ at $1 \%$

effect of being unemployed in $\mathrm{t}-1$ on the probability that a person relocates due to a new occupation between $\mathrm{t}-1$ and t. If a statistically significant correlation of the error terms occurs the unemployment variable would be endogenous in a simple probit estimation. In this case estimating the joint probabilities is the leading technique to deal with the endogenity bias (Greene 2010).

Results show that the model fits the data well. The Akaike and Bayesian information criterion are 2,1450.09 (AIC) and 22,052.48 (BIC) respectively. The likelihood-ratio (LR) Test on rho $=0\left(\chi^{2}=4.4277\right)$ suggests that the two disturbances are significantly correlated. The estimated correlation $\rho$ is with 0.5105 unequal from zero and statistically discernible $(p=0.0354)$. This shows the significance of the bivariate model. It confirms that the central estimates obtained from a univariate migration decision framework would be biased. ${ }^{3}$ The migration decision and the unemployment status should be jointly determined to account for an endogeneity bias of

\footnotetext{
${ }^{3}$ In the simple probit model about the moving decision the central unemployment variable turns out not to have a statistically significant effect on the job-related moving decision. However, as the results above show, the coefficient is biased anyways. Estimation results from pooled probit models about the moving decision and the unemployment status are very similar from those from the bivariate probit model. The coefficient's signs are all equal, computed marginal effects are similar.
} 
Table 3 Marginal effects on the Migration and unemployment probability separately, after bivariate probit

\begin{tabular}{|c|c|c|c|c|}
\hline & \multirow{2}{*}{$\begin{array}{l}\text { Job-mobil- } \\
\text { ity of the } \\
\text { Unemployed } \\
\text { dy/dx }\end{array}$} & \multirow{2}{*}{$\begin{array}{l}\text { Job-mobility } \\
\mathrm{dy} / \mathrm{dx} \\
\end{array}$} & \multicolumn{2}{|l|}{$\begin{array}{l}\text { Unem- } \\
\text { ployed (t-1) }\end{array}$} \\
\hline & & & $\mathrm{dy} / \mathrm{dx}$ & \\
\hline UNEMPL (t-1) & $-0.0012^{\mathrm{c}}$ & $-0.0023^{\mathrm{c}}$ & - & 0.0764 \\
\hline OWNER (t-1) & $-0.0029^{c}$ & $-0.0072^{\mathrm{c}}$ & - & 0.6193 \\
\hline EDUCATION & $0.0000^{\mathrm{b}}$ & $0.0002^{\mathrm{c}}$ & $-0.0088^{c}$ & 12.0381 \\
\hline SINGLE & 0.0003 & $0.0002^{\mathrm{c}}$ & $0.0274^{\mathrm{c}}$ & 0.0696 \\
\hline CHILDREN & $0.0006^{\mathrm{b}}$ & $0.0015^{\mathrm{a}}$ & $-0.0056^{\mathrm{a}}$ & 0.4127 \\
\hline O_INCOME & -0.0002 & $-0.0003^{\mathrm{c}}$ & $-0.0036^{c}$ & 1.7720 \\
\hline AGE_-20 & $-0.0011^{\mathrm{c}}$ & $-0.0020^{c}$ & $-0.0574^{c}$ & 0.0000 \\
\hline AGE_21-27 & - & - & - & - \\
\hline AGE_28-35 & 0.0000 & 0.0002 & -0.0050 & 0.1075 \\
\hline AGE_36-65 & -0.0007 & -0.0017 & 0.0040 & 0.8802 \\
\hline HEALTH & 0.0000 & $0.0003^{c}$ & $-0.0141^{\mathrm{c}}$ & 3.3710 \\
\hline GERMAN & $-0.0015^{\mathrm{b}}$ & $-0.0020^{\mathrm{c}}$ & $-0.0593^{\mathrm{c}}$ & 0.9288 \\
\hline HH-SIZE & $-0.0003^{b}$ & $-0.0008^{\mathrm{c}}$ & $0.0037^{\mathrm{c}}$ & 3.1531 \\
\hline $\begin{array}{l}\text { P_UNEMPL } \\
(\mathrm{t}-1)\end{array}$ & $0.0016^{\mathrm{a}}$ & $0.0018^{c}$ & $0.0926^{c}$ & 0.0743 \\
\hline Gender & - & - & $-0.0066^{\mathrm{c}}$ & 0.5277 \\
\hline
\end{tabular}

${ }^{a}$ significant at $10 \%$, ${ }^{\text {bat }} 5 \%$, ${ }^{\text {cat }} 1 \%$

the unemployment status. The central unemployment variable coefficient shows a significant negative sign which is discussed in detail below. The positive sign of the correlation between job motivated relocation and unemployment is counterintuitive compared to the negative sign of the unemployment variable coefficient. However, the correlation of the error terms is only affected by personal traits that are not observable (Dubin and Rivers 1989). The positive correlation suggests that individuals who have a higher probability of moving for a job than can be explained by their observed characteristics are more likely to be unemployed than explained by considered variables. Within this model it is not possible to account for the unemployment duration. Unemployment might often be a transition period between a person's decision to change jobs and the actual relocation.

Turning to the estimated coefficients in columns 2 and 4 of Table 2 most coefficients are statistically significant and have the expected sign as discussed in sect. 3. Although the sign and significance of coefficients estimated by probit models are meaningful their magnitudes are by themselves not useful. Table 3 depicts the computed marginal effects. It has to be kept in mind that in contrast to a linear model marginal effects from nonlinear models are not constant. In a linear estimation model, for example on income determinants, every year of education is supposed to have the same effect. In contrast, in non linear models the effect of education can vary between, for example the years 9 and 15 (Karaca-Mandic et al. 2011). In Table 3 the marginal effects for the respective variables $(\mathrm{dy} / \mathrm{dx})$ are computed given the sample averages of this variable $\overline{\mathrm{X}}$. The second column gives marginal effects on the moving probability only for the unemployment group. The third column shows the partial effects on the moving probability of all people in the sample. Column 4 displays the respective effects on the unemployment probability. The last column gives the average value of the variable for the dataset. These may differ from the means in Table 1 since not all observations are used in the estimation.

The following paragraph discusses the effects of variables influencing the work related moving probability given in columns 2 and 3 of Table 3. Comparing the values in columns 2 and 3 , every marginal effect turns out to be lower for the unemployed group. The unemployment situation seems to weaken the relevance of common work related moving determinants. The overall probability $(\mathrm{Pr})$ of moving due to work-related issues $\operatorname{Pr}(\mathrm{MOVE} J \mathrm{JOB}=1)$ is $0.2043 \%$. The central unemployment variable turns out to have a statistically significant negative effect on the job related moving decision. When a person is unemployed the probability of moving due to a new job decreases by 0.23 percentage points. Except for some AGE categories all other variables show statistically significant effects on the moving probability. For the group of unemployed people the variables SINGLE, O_INCOME and HEALTH are insignificant. The variable on dwelling ownership that only appears in the migration equation has a negative effect and has the highest effect on the job related moving decision compared to the remaining variables. At its average of $0.62 \%$ the moving probability decreases by 0.29 percentage points for unemployed owners and by 0.74 percentage points if a person owns her or his dwelling. The next highest marginal effect in the second column is given for the variable indicating whether the partner is unemployed. This circumstance has a positive effect on the moving decision. For the group of unemployed people the probability increases in this case by 0.16 percentage points and by 0.18 points for all people.

As discussed in sect. 3, a change of residence seems to be easier when a partner is not forced to find a new occupation as well or has to accept commuting due to the move. Being German highly decreases the mobility probability. It can be assumed that foreigners are less bound to a certain region than Germans. Having children younger than 16 years of age increases the probability to move due to a new occupation. Here the sign is not in line with the negative effect of the HH-SIZE (and the positive effect for SINGLEs in column 3 ). The moving probability may decrease for larger households since more individuals are affected. Thus, for households with young children the effects seem to work differently. It seems to be relevant that the existence of young children indicates that parents are young as well. Although most of the age categories are not statistically significant in this output it is more likely that occupational changes lead- 
ing to residency changes take place in a person's younger years. The only significant AGE category with a negative coefficient is the one representing people under 20 years of age who usually still live with their parents. The marginal effect of EDUCATION is very small but statistically significant and, as expected, positive. For all people in the sample (see column 3) the OTHER_INCOME variable shows a negative effect. Living together with a person with high income can be assumed to be a deterrent from work-related moves. The HEALTH variable has a positive influence on the moving decision of all people in the sample.

The results of the unemployment equation are given in column 4 of Table 3. Except for the AGE categories all variables show statistically significant effects. Most of the signs are as expected and discussed in section 3. Effects turn out to be much higher compared to those on the job-related moving decision. The P_UNEMPL variable indicating whether the person's partner is unemployed has the highest effect on the unemployment probability. Then the unemployment probability increases by 9.26 percentage points. It can be assumed that especially long term unemployed people are more likely to have a relationship with a person in the same distressing situation. It has often been suggested that unemployment leads to high social exclusion (Böhnke 2001). The next highest marginal effect exists for the GERMAN dummy variable. For Germans the unemployment probability decreases by 5.93 percentage points. Many studies have emphasized that foreigners are in an inferior position in the German labor market with regard to the extent and status of employment (Seebaß and Siegert 2011).

Against expectations, being SINGLE has a positive effect on the unemployment probability. This might be explained by conditions for receiving unemployment compensation. The compensation amount is based on requirements of socalled "Bedarfsgemeinschaften" (needs-based-households) following the principle of subsidiary. Unemployment compensation can only be claimed if the sum of income earned by all household members is too low to ensure subsistence level. Since the Hartz reforms, people under 25 years of age are considered to belong to the "Bedarfsgemeinschaft" of their parents. The intention of this reform was to avoid moving out of the parental home only to be entitled to higher unemployment compensation. The same incentive may often apply for couples. The marginal effect of the HH-SIZE variable is positive which is counterintuitive concerning the positive SINGLE variable. Thus, it is the smallest marginal effect of the determinants of unemployment.

In Germany a high share of the unemployed people live in single households and there is a very small tendency towards larger households. However, having CHILDREN decreases the unemployment probability. Women who do not work may not be registered as unemployed due to other financial resources such as the spouse's income. This may also be an explanation for the lower unemployment probability for women. Being female decreases the probability by 0.66 percentage points. Furthermore the probability decreases with every year of EDUCATION at a mean of 12 years by 0.88 percentage points. As expected, HEALTH has a significant influence on the unemployment probability.

\section{Conclusion}

This paper examines the willingness of the unemployed people to relocate for a new job compared to the mobility of employed workers. It is assumed that the two binary responses are interrelated due to the existence of unobserved variables influencing both the migration decision and the unemployment status. A bivariate probit model with structural shift is applied. The model tests whether unobserved characteristics in the migration and unemployment equations are correlated and accounts for endogeneity by jointly determining the two outcomes. Empirical findings confirm that the error terms of the two equations are correlated. In addition, the model estimates the effects of main individual moving and unemployment determinants of German individuals. The results indicate that the work related moving decision is negatively influenced by a dwelling ownership. In addition, an unemployed partner and a migration background can have a positive influence on the moving decision and the unemployment probability. Furthermore, the group of unemployed are often single and in inferior health condition.

The results show that the unemployment status variable decreases the work-related moving probability. In addition other main moving determinants have lesser effects on the group of the unemployed. In Germany, job-motivated migration is often an investment decision made by people who are successful in their occupational field. Most unemployed people do not seem to consider relocation as an option to escape from frustrating circumstances. This has been the result of IAB-surveys among unemployed people examining the willingness to make concessions for a new occupation. On the one hand most of the unemployed people were willing to change their profession and would accept inconvenient working hours, longer commuting ways and even a lower income (at least temporarily). On the other hand the concession to relocated was only acceptable to a small number of unemployed people. In a survey from 2000 , conducted among all (also former) unemployed workers, about $66 \%$ of the workers in the East and $61 \%$ in the West were not willing to move for a new occupation (Brixy and Christensen 2002). In 2005, the IAB conducted a survey among people receiving ALG II who were predominantly long-term unemployed workers. Here even $83 \%$ expressed their unwillingness to relocate for a new occupation (Bender et al. 2007). 
There are different possible explanations for the lower mobility of unemployed people. In economic terms these explanations can be defined as immaterial and material moving costs that appear to exceed the benefits of moving. Due to failure and disappointment in an occupational field, family and private relationships in the close surroundings of the residence are presumable valued higher than a new distant job by the (long-term) unemployed. It is often suggested that individuals with lower productivity or unobserved characteristics leading to a higher unemployment probability are not as flexible and adaptable as other. Furthermore, negative duration dependence might occur: these soft skills can be lost during long periods of unemployment (Steiner 2001). As early as 1993, Jahoda in the famous study on the social impact of unemployment in a small community (Marienthal) pointed out the enormous negative psychic consequences of unemployment, especially in terms of resignation.

Furthermore, material moving costs can be assumed to be deterrents from moving. Long-terms unemployment usually leads to precarious financial situations. Moving expenses are usually paid by the employment agency once the workrelated migration is approved as being necessary for taking up a new occupation. However, in addition to the rent and gas for a moving truck, other costs are expected to incur. In addition, the benefits of moving, especially for people with low qualification profiles, are often small since the potential wages are often very close to unemployment compensation. Furthermore, regional varying living costs often limit the benefits of moving. Further research should address which fields are predominantly relevant for the lower moving probability of the unemployed.

Although most people are regionally bound to a particular area, for many individuals personal incentives outbalance immaterial and material moving costs. This study points out that being unemployed highly decreases the work-related moving probability. Effects of central moving determinants and potential moving incentives are much more distinct for employed people. For labor market policy, these results depict the potential to reduce unemployment rates in certain German regions. Political decision makers should try to create incentives for the unemployed to motivate them to relocate for a new occupation. The German Constitution grants the right of abode. No one can be forced to move for a new occupation. Thus, this study demonstrates that selfselection is highly relevant to the work-related moving decision. Selection is usually assumed since moving incentives are presumably higher for individuals who are more able or higher motivated in occupational field (Chiswick 1978). While relocation is merely considered as a new challenge by employees, it can be an option to escape a highly distressing situation for a long-term unemployed person. More effort is therefore also requested on the side of the supervis- ing employment agencies. They should propose distant job offers for the unemployed to decrease their moving barriers. Furthermore their regional interchange is highly important in order to make use of the full potential of labor demand and human capital.

Acknowledgments I would like to thank Prof. Beate Jochimsen, Prof. Viktor Steiner and Dr. Jan Goebel. Furthermore, I would like to thank Prof. Claus Schnabel and both reviewers for their important and insightful comments. I also gratefully acknowledge the helpful comments and suggestions from colleagues at the Berlin School of Economics and Law and the Free University Berlin.

\section{References}

Ahn, N., de la Rica, S., Ugidos, A.: Willingness to move for work and unemployment duration in Spain. Economica 66, 335-357 (1998)

Arntz, M.: The geographical mobility of unemployed workers, evidence from West Germany. ZEW Discuss. Pap. 05(34), 1-43 (2005)

Bender, S., Koch, S., Meßmann, S., Walwei U.: Was muten sich Arbeitslose zu? Lohnkonzessionen von ALG-II-Empfängern. IAB Discussion Paper 23, 1-40 (2007)

Böhnke, P.: Prekäre Lebenslagen und soziale Teilhabe, Ein Vorschlag zur Messung von Ausgrenzungstendenzen. Paper presented at the Arbeitstagung der Sektion Soziale Indikatoren der Deutschen Gesellschaft für Soziologie (DGS) in Zusammenarbeit mit dem DIW, November 2001 zum Thema: "Soziale Exklusion und Inklusion: Indikatoren und Berichtssysteme für Wissenschaft und Politik" (2001)

Brixy, U., Christensen, B.: Wie viel würden Arbeitslose für einen Arbeitsplatz in Kauf nehmen? IAB Kurzbericht 25 (2002)

Bundesagentur für Arbeit: Der Arbeitsmarkt in Deutschland, Struktur der Arbeitslosigkeit. Arbeitsmarktberichterstattung - Mai 2012. Bundesagentur für Arbeit online: http://statistik.arbeitsagentur.de/ Statischer-Content/Arbeitsmarktberichte/Berichte-Broschueren/ Arbeitsmarkt/Generische-Publikationen/Strukturen-der-Arbeitslosigkeit-2012-05.pdf (2012). Accessed 14 Feb 2014

Chiswick, B.R.: The effect of americanization on the earnings of foreign-born men. J. of Polit. Economy 86, 897-922 (1978)

DaVanzo, J.: Does unemployment affect migration? evidence from Micro Data. Rev. Econ. Stat. 60(4), 504-514 (1978)

Dubin, J.A., Rivers, D.: Selection bias in linear regression, logit and probit models. Soc. Methods \& Res. 18, 360-390 (1989)

Dujardin, C., Goffette-Nagot F.: Neighbourhood effects on unemployment? A test à la Altonji. GATE Work. Pap. 09(24), 1-46 (2009)

Dustmann, C., Glitz, A.: Migration and education. In: Hanushek, E. A., Machin, S., Woessmann, L. (eds.) Handbook of the Economics of Education 4, pp. 327-429. North-Holland Amsterdam (2011)

Glocker, D., Steiner, V.: Returns to education across Europe, a comparative analysis for selected EU countries. Freie Universität Berlin Work. Pap. 15, 1-34 (2011)

Greene, W.H.: Econometric analysis, sixth edition, Pearsons International Edition. Pearson, Prentice Hall, New Jersey (2008)

Greene, W.H.: Gender economics courses in liberal arts colleges: further results. J. Econ. Educ. 29(4), 291-300 (2010)

Greenwood, M.J.: Research on internal migration in the United States: a survey. J. Econ. Lit. 13(2), 397-433 (1975)

Gross, E.P., Schöning, N.C.: Search time, unemployment and the migration decision. J. Hum. Res. 19, 570-579 (1984) 
Guo, S., Fraser, M.W.: Propensity score analysis, statistical methods and applications. Advanced Quantitative Techniques in the Social Sciences Series 12, Sage, Los Angeles (2013)

Haas, A.: Arbeitsmarktausgleich, Regionale Mobilität gestiegen. IABKurzbericht 4, 1-7 (2000)

Haisken-DeNew, J.P., Frick J.R.: Desktop Companion to the German Socio-Economic Panel Study (GSOEP), 1-202 (2001)

Heckman, J.J., Ichimura, H., Todd P.: Matching as an econometric evaluation estimator. Rev. Econ. Stud. 65, 261-294 (1998)

Jahoda, M., Lazarsfeld, P.F., Zeisel, H.: Die Arbeitslosen von Marienthal. Ein soziographischer Versuch über die Wirkung langandauernder Arbeitslosigkeit. Hirzel, Leipzig (1933)

Juerges, H.: Beruflich bedingte Umzüge von Doppelverdienern, Eine empirische Analyse mit Daten des SOEP. Z. Soziol. 27(5), 358377 (1998)

Karaca-Mandic, P., Norton, E.C., Dowd, B.: Interaction terms in nonlinear models. HSR: Health Services Res. 47(1), Part I, 255-274 (2011)

Karr, W., Koller, M., Kridde, H., Werner, H.: Regionale Mobilität am Arbeitsmarkt. Mitt.A.B. 20(2), 129-144 (1987)

Kitching, R.: Migration behaviour among the unemployed and low skilled. In: Johnston J., Salt J. (eds.) The Internal Geographical Mobility of Labour in the Developed Worlds, pp. 172-190. David Foulton, London (1990)

Linneman, P., Graves, P.E.: Migration and job change: a multinominal logit approach. J. Urban Econ. 14, 263-279 (1983)

Long, L.H.: Migration differentials by education and occupation: trends and variations. Demography 10(2), 243-258 (1973)

Maddala, G.S.: Limited-dependent and qualitative variables in econometrics. Econom. Soc. Monogr. 3, University Press, Cambridge (1983)

Massey, D. S., Arango, J., Hugo, G., Kouaouci, A., Pellegrino, A.: Theories of International Migration: A Review and Appraisal. Population and Devel. Rev. 19(3), 431-466 (1993)
Mincer, J.: Family migration decision. NBER Work. Pap. Series 199, $1-54$ (1977)

Rossi, P.H.: Why families move. Sage, London (1980)

Seebaß, K., Siegert, M.: Migranten am Arbeitsmarkt in Deutschland. Integrationsreport, Teil 9, Work. Pap. 36, 1-84 (2011)

Sjaastad, L.A.: The costs and returns of human migration. J. Polit. Econ. 70(5), 80-93 (1962)

Steiner, V.: Unemployment persistence in the West German labour market: negative duration dependence or sorting? Oxford B. Econ. Stat. 63(1), 91-113 (2001)

Todaro, M.P.: A model of labour migration and urban unemployment in less developed countries. Am. Econ. Rev. 59(1), 138-148 (1976)

Verbeek, M.: A Guide to Modern Econometrics, second edition. John Wiley \& Sons, Ltd., England (2004)

Windzio, M.: Zwischen Nord- und Süddeutschland: Die Überwindung räumlicher Distanzen bei der Arbeitsmarktmobilität. Z. Arbeitsmarktforschung 37, 29-44 (2004)

Windzio, M.: The exit option of labour migration from East to West Germany: individual and contextual determinants of unemployed workers' geographic mobility. In: Kolb, H., Egbert, H. (eds.), Migrants and Markets, Perspectives from Economics and the Other Social Sciences, pp. 56-80. Amsterdam University Press, Amsterdam (2008)

Winship, C., Mare, R.: Models for sample selection bias. Annu. Rev. Sociol. 18 (1992)

Tanja Fendel has studied economics in Rostock and Berlin. Since 2012 she is a Ph.D. student at the Free University of Berlin and lecturer at the Berlin School of Economics and Law. Her dissertation is about regional labor market disparities and migration. 